\title{
The First Electric Clock
}

\section{ALEXANDER BAIN'S GOLD CONTAC'T SYSTEM}

\section{A. G. Thomson}

Royal Scottish Museum, Edinburgh

In March 1837 Alexander Bain, a journeyman clockmaker from Wick in the far north of Scotland, came to London at the age of 26 to seek employment. He obtained lodgings and a workshop, first in Wigmore Street and later in Oxford Street, and besides practising his craft he attended lectures at the Polytechnic Institute, having as he later wrote, 'some knowledge of electricity and a strong desire to know more'.

Before long he had conceived the idea of applying the new concepts of electro-magnetism to timekeeping. At that time, of course, the idea that electricity could be carried along wires and could be made to do work had only recently become established and there was very little background knowledge available. However, Bain persisted with his experiments and by the summer of 1840 had designed and built not only a model of an electric clock but also the prototype of a printing electric telegraph.

At this stage Bain began to cast about for someone "to join him in furthering his invention". Now it was in the very month of Bain's arrival in London that Cooke and Wheatstone had agreed to form a partnership, and this uneasy collaboration of two such very
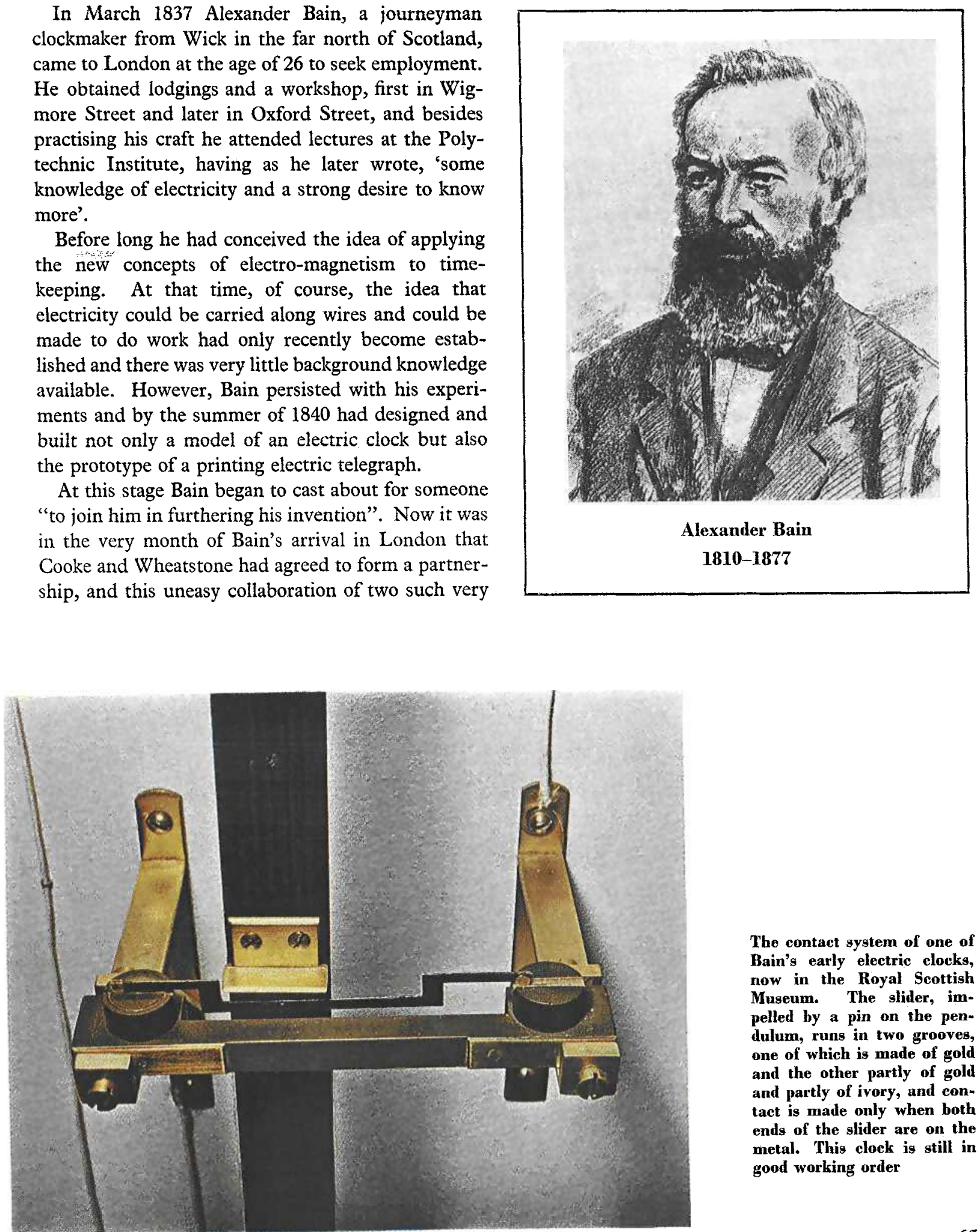

The contact system of one of Bain's early electric clocks, now in the Royal Scottish Museum. The slider, impelled by a pin on the pendulum, runs in two grooves, one of which is made of gold and the other partly of gold and partly of ivory, and contact is made only when both ends of the slider are on the metal. This clock is still in good working order 
different men had led almost immediately to the filing of their first patent for an electric telegraph. Their achievements had become well known by 1840 , and it was not unnatural that Bain should be referred to Professor Wheatstone, who had himself been thinking along the lines of an electric clock. Their first meeting took place at King's College, London, on August 1st, 1840 , when Bain produced his drawings of both devices. Wheatstone was interested, and arranged a second meeting at his house in Conduit Street for August 18th for Bain to bring along his models. A vague arrangement was entered into at this meeting, under which Wheatstone paid Bain $£ 5$ for his model of the printing telegraph, to be followed by $£ 50$ if it became commercially profitable, but advised him to postpone all work on the electric clock.

Unfortunately it was from this meeting that there stemmed a long and embittered controversy as to who was the true inventor of the electric clock. Bain, with his friend John Barwise, the well known chronometer maker, filed his patent-a lengthy and complicated specification-on October 10th and it was granted, as No. 8783, on January 11 th, 1841 . In the meantime, on November 26th, 1840, Wheatstone exhibited an electric clock at the Royal Society!

The argument and counter-argument raged for some years and involved recourse to the Courts, where it was established that Bain was the first to devise an electric clock. One result was that he was appointed manager for Scotland of the Electric Telegraph Company, which was a Wheatstone foundation, and on the face of all their clocks was to be engraved "A. Bain, Inventor".

Bain was the first to maintain a clock pendulum in motion by means of electromagnetic impulses. The sequential switching to energise the coil was achieved by means of a cranked bracket actuated by the pendulum and rubbing on an ivory or ebonite block in which were inlaid contacts of gold. The actual motion was induced by the attraction of a sequentially energised coil which formed the pendulum bob and which swung over a group of small permanent magnets enclosed in a brass tube.

Bain had chosen perhaps better than he knew in his selection of gold as his contact material. Though perhaps rather soft, its freedom from oxidation and its low electrical resistance combined to give success to an electrical circuit where losses had perforce to be kept to a minimum.

In the Royal Scottish Museum there are two going examples of Bain's clocks, one of which is thought to be his No. " $O$ " or original model, and both are quite reliable; they operate not off the original earth battery but from a $1 \frac{1}{2}$ volt Leclanché cell.

It is perhaps interesting to note that some 60 years after Bain's invention the Bentley Engineering Company of Leicester filed patents for what seems in all respects to have been a replica of Bain's clock. But it is to Alexander Bain that we owe the first successful electrically maintained clock and it depended for its success largely on his choice of gold as the contact material.

THIS metal, as has been said, becomes dense because of its thorough tempering 1 and its perfect and uniform elemental mixture, and of such a density that it is given not only an ordinary permanence but almost an incorruptibility and an incapacity to contain any superfluous material, even if it is subtle and in small amount. For this reason it does not rust, even though it be in the earth or in water for a long time, for neither of these has any effect on it, nor does fire, which has the power to reduce to ashes or dissolve every created thing; indeed gold not only defends itself from fire but continually purifies itself therein and becomes more beautiful; nor does it have any effect on the senses of smell or taste, nor is it poisonous if it is eaten either intentionally or by accident-indeed as a medicine it is beneficial in certain illnesses.

From the translation by

Cyril Stanley Smith and Martha Teach Gnudi,

New York, $194^{2}$
VANNOCCIO BIRINGUCCIO

De La Pirotechnia

Venice, $154^{\circ}$ 